\title{
ANALISIS PROMOSI DARI MULUT KE MULUT, CITRA MEREK DAN KUALITAS JASA PENGARUHNYA TERHADAP KEPUTUSAN MEMILIH PELATIHAN PRAKERJA DI PINTARIA \\ Andika Rohani ${ }^{1}$, Lucy Nancy Simatupang ${ }^{2}$, GL. Hery Prasetya ${ }^{3}$ Universitas Satya Negara Indonesia ${ }^{1.2 .3}$ \\ Andikarohani@gmail.com ${ }^{1}$, lucynancysim@gmail.com ${ }^{2}$, herianov@gmail.com ${ }^{3}$
}

\begin{tabular}{lcl}
\hline Received: & Accepted: & Published: \\
1 Januari 2022 & 15 Februari 2022 & 22 Februari 2022 \\
\hline
\end{tabular}

\begin{abstract}
ABSTRAK
Penelitian ini bertujuan untuk mengetahui pengaruh Promosi Dari Mulut Ke Mulut, Citra Merek dan Kualitas Jasa terhadap Keputusan Pemilihan Pelatihan Kartu Prakerja di Pintaria. Data yang digunakan adalah data primer yang dikumpulkan melalui penyebaran kuesioner kepada 50 orang responden yang pernah memilih pelatihan Prakerja di Pintaria. Metode yang digunakan pada penelitian ini merupakan metode kuantitatif dan hasil penelitian berdasarkan jawaban responden dengan menggunakan skala likert. Metode analisa data yang digunakan dalam penelitian ini adalah Uji Regresi Linier Berganda, Uji F, Uji t dan Koefisien Determinasi dengan bantuan SPSS 24.

Hasil penelitian menunjukan bahwa secara simultan (Uji F) terdapat pengaruh yang signifikan antara variabel Promosi Dari Mulut Ke Mulut, Citra Merek, dan Kualitas Jasa terhadap Keputusan Memilih . Secara parsial (Uji t) Promosi Dari Mulut Ke Mulut berpengaruh signifikan terhadap Keputusan Memilih dan Kualitas Jasa berpengaruh signifikan terhadap Keputusan Memilih, sedangkan Citra Merek tidak berpengaruh terhadap Keputusan Memilih.
\end{abstract}

Kata Kunci: Promosi Dari Mulut Ke Mulut, Citra Merek, Kualitas Jasa, dan Keputusan Memilih

\begin{abstract}
This study aims to determine the influence of word-of-mouth promotion, brand image and service quality on the decision to choosing the training of prakerja at Pintaria. The population in this study were all Prakerja participants of Pintaria. The sample in this study amounted to 50 respondents. The design used in this study is a Causal. The method used in this study is a quantitative method and the result of the study are based on respondent answer using the Likert Scale. The data analysis method used in this research is Multiple Linear Regression Test, F Test, $t$ Test and Coefficient of Determination with the help of SPSS 24.

The result showed that simultaneously ( $\mathrm{F}$ Test) there was a significant effect between the variables Word-Of-Mouth Promotion (X1), Brand Image (X2), and Service Quality (X3) on decision to choosing (Y). Partially (t Test) Word-Of-Mouth Promotion (X1) has a significant effect on decision to choosing, and Service Quality (X3) has a significant effect on decision to choosing, while Brand Image (X2) has no effect and is not significant to decision to choosing (Y).
\end{abstract}

Keywords: Prakerja, Word-Of-Mouth Promotion, Brand Image, Service Quality, and Decision To Choosing 


\section{PENDAHULUAN}

Berawal dari sebuah gagasan pada 24 Februari 2019 presiden Bapak Joko Widodo menyampaikan mengenai Program Kartu Prakerja. Program Kartu Prakerja adalah sebuah program bantuan dari pemerintah untuk mendukung, menunjang dan menaikan tingkat keterampilan sumber daya manusia di Indonesia. Program tersebut bertujuan untuk mengembangkan SDM Indonesia lebih kompetitif, kompetensi, produktivitas, dan daya saing berpengalaman dengan cara memberikan pelatihan agar dapat bersaing didunia industri. Gagasan ini muncul dikarenakan tingkat kesadaran sumber daya manusia di Indonesia mengenai keterampilan dan daya saing sangat lemah, itu terbukti dari survey yang dilakukan Prakerja di laporan kerjanya menyatakan dari $135.000,000$ jumlah orang angkatan kerja ada $90 \%$ belum pernah mengikuti pelatihan bersertifikat dan 7.000,000 jumlah orang pengangguran 2019 terdapat $91 \%$ belum pernah mengikuti pelatihan bersertifikat. Tidak dapat disangkal bahwa tingkat keterampilan sumber daya manusia di Indonesia masih sangat rendah, sebagaimana ditunjukkan dalam laporan Bank Dunia 2018 bahwa Human Capital Index (HCI) Indonesia menempati urutan ke-87 dari 157 negara. Oleh sebab itu gagasan Bapak Joko Widodo mengenai program Kartu Prakerja akan mampu untuk memperbaiki tingkat kualitas sumber daya manusia Indonesia dan harapannya juga bisa berdaya saing dengan tenaga luar asing.

Program Kartu Prakerja dapat terealisasi pada April 2020 dimulai dari gelombang I sampai dengan pada bulan Maret 2021 sudah ada 16 gelombang dan pada akhir 2020 sudah berjumlah pendaftar Kartu Prakerja terdapat 43.800,000 dan jumlah penerima Kartu Prakerja terdapat $5.000,000$, Bantuan dana yang diberikan pemerintah kepada peserta Prakerja ialah sebesar Rp 3.500,000 per peserta dari jumlah dana tersebut dapat diuraikan menjadi $\mathrm{Rp} 1.000,000$ untuk biaya pelatihan, $\mathrm{Rp} 2.400,000$ untuk biaya penunjang keterampilan usai pelatihan, dan $\mathrm{Rp}$ 100,000 untuk mengisi formulir evaluasi pelatihan.Dalam melaksanakan program tersebut, tidak dilakukan oleh pemerintah sendirian tetapi bekerjasama dengan platform digital yang menyediakan pelatihan baik online maupun offline. Tentu dari jumlah angka sumber daya manusia yang belum mengikuti pelatihan menjadi sebuah peluang bagi platform digital untuk berkompetisi mendapatkan jumlah peserta sebanyak-banyaknya dikarenakan dana bantuan dari pemerintah akan menjadi sebuah laba bagi perusahaan.

Untuk menjadi mitra pemerintah dalam melaksanakan program Prakerja tidak dengan skema pengadaan barang dan jasa tetapi pemerintah memberikan ketentuan yang berlaku sesuai dengan peraturan yang menyatakan "Pemilihan Platform Digital dan lembaga Pelatihan sebagaimana dimaksud dalam Pasal 6 ayat (2) tidak termasuk lingkup pengaturan pengadaan barang/jasa (PBJ) pemerintah namun tetap memperhatikan tujuan, prinsip, dan etika pengadaan barang jasa pemerintah," demikian Pasal 31 A Perpres 76/2020 dikutip, Jumat (10/7/2020). Hal tersebut diperkuat dari informasi laporan kerja Prakerja pada hal 34 poin ketiga mengenai "Kolaborasi" sebagai berikut:

1. Tidak memakai skema pengadaan barang dan jasa

2. Berbagi beban kepada mitra Platform Digital melayani masyarakat

3. Mitra Platform Digital dan Mitra Pembayaran bersaing agar memberikan pelayanan yang terbaik

4. Lembaga pelatihan juga bersaing memberikan pelayanan terbaik

5. Gratis daftar dan keluar

Dari poin-poin diatas dapat diambil kesimpulannya bahwa para mitra Prakerja sama seperti platform digital biasa lainnya yaitu menjual produknya dan bersaing dengan kompetitor secara sehat untuk mendapatkan jumlah pendaftar pelatihan sebanyak-banyaknya untuk dapat 
mensukseskan tujuan dari program pemerintah yaitu keterampilan dan juga mendapatkan laba dari hasil penjualan pelatihan Prakerja. Adapun mitra platform pelatihan resmi pemerintah dalam menjalankan program Prakerja sebagai berikut SkillAcademy (ex), Pintaria, Disnaker, Sekolah.mu, MauBelajarApa, Tokopedia, Bukalapak dan Pijar Mahir.Untuk mendapatkan jumlah pendaftar yang banyak para mitra bersaing memberikan pelatihan yang baik, promosi yang menarik dan berbagai strategi untuk dapat menarik para pemegang Kartu Prakerja memilih platform pelatihan yang mereka mau. Para mitra pun melakukan berbagai aksi strategi untuk bersaing dengan kompetitor. Pintaria merupakan salah satu platform digital dari delapan mitra resmi program Prakerja. Di dalam website atau platform yang dikelola Pintaria terdapat berbagai pelatihan Prakerja yang ditawarkan sehingga para peserta bisa memilih pelatihan yang mereka butuhkan sesuai kepada keahlian yang mereka inginkan. Platform tersebut sudah berdiri dari tahun 2004 mengelola sistem pembelajaran akademik perguruan tinggi dan sampai sekarang mengalami perkembangan pesat menciptakan platform pelatihan sejak dari tahun 2017.

Sejak terpilihnya kembali Bapak Joko Widodo menjadi presiden, Pintaria sudah mulai mempersiapkan diri untuk bergabung dalam pelaksanaan program Prakerja tersebut. Persiapan pelatihan sudah dilaksanakan 1 tahun kurang sebelum Prakerja terealisasi, Pintaria mengikuti segala proses prosedur untuk dapat menjadi mitra resmi yang berarti Pintaria sudah mempunyai persiapan yang matang untuk menyambut para pendaftar pelatihan Prakerja.Dalam finance.detik Bapak Direktur Kemitraan \& Komunikasi PMO Kartu Prakerja, Panji Winanteya Ruky mengatakan dari 456.256 peserta gelombang pertama dan kedua, sudah ada 360.650 orang yang sudah menggunakan biaya pelatihannya. Dari angka itu, tercatat ada 219.489 orang yang sudah menyelesaikan satu pelatihan. "4 teratas adalah Skill Academy, Sisnaker, Pintaria dan Tokopedia". Pada bulan Mei 2020 dilansir dari cyberthreat.id bahwa manajemen pelaksanan Prakerja mengumumkan dari Rp120,000,000,000 yang terjual saat itu, materi yang paling banyak laku berikut urutannya

Peringkat Penjualan Pelatihan Platform Prakerja

\begin{tabular}{|l|l|l|l|}
\hline No & Nama Platform & Presentase & Nilai Rupiah \\
\hline 1 & Skill Academy & $68,9 \%$ & Rp 82.990,000,000 \\
\hline 2 & Sisnaker & $10,9 \%$ & Rp $13.140,000,000$ \\
\hline 3 & Pintaria & $5,7 \%$ & Rp $6.890,000,000$ \\
\hline 4 & Tokopedia & $5,3 \%$ & $\operatorname{Rp~} 6.400,000,000$ \\
\hline 5 & Bukalapak & $4 \%$ & Rp 4.790,000,000 \\
\hline 6 & Sekolahmu & $3 \%$ & $\operatorname{Rp~3.670,000,000~}$ \\
\hline 7 & Maubelajarapa & $1,4 \%$ & Rp 1.690,000,000 \\
\hline 8 & Pijar Mahir & $0,7 \%$ & Rp 900,000,000 \\
\hline
\end{tabular}

Sumber: cybertheart.id (2021)

Pada tabel tersebut menunjukan bahwa Pintaria hanya menjadi peringkat ketiga dari 8 mitra dari segi penjualan pelatihan. Maka itu Pintaria perlu melakukan strategi-strategi yang dapat mempengaruhi para peserta mau memutuskan memilihnya. Maka itu perlu adanya evaluasi tentang pengaruh keputusan para peserta memilih Pintaria, bisa dari banyak faktor namun yang sudah dilaksanakan Pintaria dalam strategi pemasarannya yakni Promosi dari mulut ke mulut, membangun citra merek, dan meningkatkan kualitas jasa bisa mampu diharapkan meningkatkan penjualan.

Fenomena dalam Promosi Dari Mulut Ke Mulut. Promosi dari mulut ke mulut merupakan 
aksi komunikasi atau aksi promosi yang dilakukan perseorangan/komunitas yang sudah menggunakan produk tersebut melalui media digital ataupun secara langsung. Bagusnya komentar atau opini dari peserta dapat menaikan jumlah peserta yang memilih Pintaria sebagai media mencari pelatihan Prakerja. Dalam promosi dari mulut ke mulut yang sudah dilakukan Pintaria adalah menyediakan sebuah kolom ulasan mengenai kesan para peserta memilih Pintaria sebagai media mencari pelatihan Prakerja serta menyediakan sebuah kode referral untuk dapat disebarkan oleh para peserta untuk mendapatkan dan mengumpulkan poin hadiah yang disediakan oleh Pintaria. Namun, dalam hastag \#pintaria \#prakerjapintaria masih sedikit akun-akun Instagram yang memberikan kesannya setelah memilih produk pelatihan selain itu masih ada produk yang belum terisi kolom ulasan dari masing-masing akun peserta Pintaria. Dalam penelitian sebelumnya promosi dari mulut ke mulut berpengaruh terhadap Keputusan Memilih menurut (Kiki Joesyiana, 2018) sedangkan menurut (Uga Saputra, Irda, Reni Yuliviona, 2019) promosi dari mulut ke mulut tidak berpengaruh.

Fenomena Citra Merek. Citra merek yang bagus bisa memberikan manfaat positif agar mampu menarik konsumen menggunakan produk berulang-ulang dan sebaliknya, citra merek yang buruk membuat orang banyak berpikir untuk menggunakan merek tersebut. Pintaria tidak hanya punya produk pelatihan tetapi juga menjual jasa pendaftaran pendidikan ke universitas dengan program blended learning di berbagai universitas akreditasi yang baik dan menyediakan aplikasi "Learning Management System" bagi universitas yang sudah menjadi mitra dari Pintaria, itu yang menjadikan Pintaria memiliki reputasi yang baik dalam hal ilmu, pendidikan, pelatihan dan edukasi teknologi sehingga mampu meyakinkan para peserta Prakerja memilih Pintaria. Namun, dalam website mediakonsumen.com Levan mengunggah sebuah cerita tentang ketidak profesional Pintaria. Dari penelitian terdahulu citra merek berpengaruh terhadap Keputusan Memilih (Muhammad Aries Firnanda, Asnawati, (2017) sedangkan menurut (Desy Irana Dewi Lubis, Rahmat Hidayat, 2017) citra merek tidak berpengaruh terhadap Keputusan Memilih.

Fenomena dalam Kualitas Jasa/Layanan. Kualitas Jasa/Layanan yang baik dapat meningkatkan Keputusan Memilih atau keputusan memilih. Pintaria ialah sebagai jasa dalam bentuk digital atau sebagai media digital bagi para peserta kartu Prakerja memilih pelatihan dari berbagai lembaga pelatihan yang ditawarkan oleh Pintaria. Pintaria memberikan fitur dan proses pelatihan yang mudah dipakai dan dipahami sampai mereka mendapatkan sertifikat. Namun, halaman facebook Pintaria X Kartu Prakerja atas nama Trisna Wati memberikan keluhan bahwa pelatihan dalam website Pintaria tidak dapat diakses ujian terakhirnya. Dari penelitian terdahulu kualitas jasa berpengaruh terhadap Keputusan Memilih (Muhammad Aries Firnanda, Asnawati, 2017) dan sedangkan menurut (Desy Irana Dewi Lubis, Rahmat Hidayat, 2017) kualitas jasa tidak berpengaruh terhadap Keputusan Memilih.

Berdasarkan pada uraian latar belakang masalah diatas maka dapat diajukan sebuah penelitian dengan judul: ANALISIS PENGARUH PROMOSI DARI MULUT KE MULUT, CITRA MEREK DAN KUALITAS JASA PENGARUHNYATERHADAP KEPUTUSAN MEMILIH PELATIHAN PRAKERJA DI PINTARI

\section{KAJIAN TEORI}

\section{Keputusan Memilih}

Menurut Anang Firmansyah (2019:3) Keputusan Memilih adalah bagian dari perilaku konsumen memilih, membeli, memakai serta memanfaatkan produk, jasa, serta gagasan, atau pengalaman dalam rangka memuaskan kebutuhan dan keinginan konsumen. Dari pengertian 
tersebut dapat diartikan bahwa keputusan memilih merupakan bagian penting dalam bisnis agar konsumen dapat puas dengan barang, jasa, ide atau pengalaman yang ditawarkan oleh penjual

\section{Faktor yang mempengaruhi keputusan pembelian}

Beberapa faktor yang dapat mempengaruhi konsumen didalam memutuskan melakukan pembelian produk, faktor tersebut bisa dari eksternal maupun internal.

Menurut Kotler dan Armstrong (2019:159), faktor-faktor yang dapat mempengaruhi perilaku konsumen diantarannya adalah:

a. Faktor Budaya

Faktor budaya mempunyai pengaruh yang luas dan mendalam pada perilaku konsumen.

Faktor budaya terdiri dari:

- Budaya (Culture), budaya adalah penyebab keinginan dan perilaku seseorang yang paling dasar.

- Sub-Budaya (Sub-Culture), Setiap budaya mengandung subkultur (subkultur) yang lebih kecil dari atau kelompok orang yang berbagi sistem nilai berdasarkan pengalaman dan situasi hidup yang sama.

- Kelas sosial, Kelas sosial adalah pembagian yang relatif permanen dan bertahap dalam masyarakat di mana para anggotanya berbagi nilai, minat, dan perilaku yang sama.

b. Faktor Sosial (Social Factor)

Perilaku konsumen juga dipengaruhi oleh faktor-faktor sosial, seperti kelompok kecil, keluarga, serta peran dan status sosial konsumen. Berikut ini adalah sebagai berikut:

- Kelompok referensi

Seseorang adalah setiap kelompok yang memiliki pengaruh langsung (tatap muka) atau tidak langsung terhadap sikap atau perilaku orang tersebut.

- Keluarga

Organisasi pembelian konsumen yang paling penting dalam masyarakat dan anggota keluarga mempresentasikan kelompok referensi utama yang paling berpengaruh. Ada dua keluarga dalam kehidupan pembeli Pertama adalah keluarga orientasi yang terdiri dari orangtua dan saudara kandung. Sedangkan yang kedua adalah keluarga adalah keluarga prokresi yaitu pasangan dan anak-anak.

- Peran dan status

Orang-orang yang bekerja di banyak kelompok, komunitas, dan organisasi kelompok menjadi sumber informasi yang penting dan membantu menentukan norma perilaku.

c. Faktor Pribadi

Keputusan pembelian juga dipengaruhi oleh karakteristik pribadi faktor pribadi ini terdiri dari:

- Usia dan tahap siklus hidup

Orang membeli barang atau jasa yang berbeda dalam perjalanan hidup mereka, konsumen juga dibentuk oleh siklus hidup keluarga, orang dewasa mengalami perjalanan dan perubahan sepanjang hidup mereka.

- Pekerjaan dan lingkungan ekonomi

Pekerjaan juga mempengaruhi perilaku konsumen: pemasar mencari kelompok pekerjaan yang memiliki minat di atas rata-rata dalam produk dan layanan mereka dan bahkan memberikan produk yang khusus untuk kelompok pekerjaan mereka.

- Kepribadian dan Konsep diri

Setiap orang memiliki karakteristik pribadi yang mempengaruhi perilaku pembelian mereka. Yang dimaksud dengan kepribadian adalah seperangkat sifat psikologis 
manusia yang membangkitkan respons yang relatif konstan dan tahan lama terhadap rangsangan lingkungan (termasuk perilaku berbelanja)

- Gaya hidup

Orang-orang sub budaya, kelas sosial, dan pekerjaan yang sama mungkin mempunyai gaya hidup yang cukup berbeda.

d. Faktor Psikologis

Selanjutnya pilihan pembelian seseorang dipengaruhi oleh empat faktor psikologis utama, yaitu:

- Motivasi adalah kebutuhan dengan tekanan kuat yang mengarahkan seseorang mencari kepuasan.

- Persepsi, adalah proses di mana orang memilih, mengatur, dan menginterprestasikan informasi untuk membentuk gambaran dunia yang berarti.

- Pembelajaran, menggambarkan perubahandalam perilaku seseorang yang timbul dari pengalaman.

- Keyakinan dan Sikap, keyakinan adalah pemikiran deskriptif yang dimiliki seseorang tentang sesuatu. Dan sikap adalah menggambarkan evaluasi, perasaan, dan tendesi yang relatif konsisten dari seseorang terhadap sebuah objek atau ide.

\section{Promosi Dari Mulut Ke Mulut}

Menurut Kotler dan Keller (2016:652) Promosi dari mulut ke mulut merupakan cara untuk melibatkan pelanggan sehingga mereka akan memilih untuk berbicara secara positif dengan orang lain tentang produk, layanan, dan merek. Dari pernyataan teori ini maka bisa ditekankan bahwa promosi dari mulut ke mulut ialah sebuah bentuk informasi positif tentang produk

\section{Citra Merek}

Menurut Kotler \& Keller (2018:148) mendefinisikan citra merek sebagai persepsi dan keyakinan konsumen yang tercermin dalam asosiasi yang tersimpan di benak konsumen. Dari pengertian teori ini dapat dikatakan bahwa citra merek ialah sebuah kesan yang ada dalam benak konsumen.

\section{Faktor yang mempengaruhi citra merek}

Menurut Keller (2020) dalam, faktor-faktor yang mempengaruhi Citra Merek berbasis pelanggan yaitu sebagai berikut:

a. Arti Penting Merek (Brand Salience), pada aspek kesadaran merek, seberapa sering dan seberapa mudah suatu merek diingat dan dikenali dalam situasi yang berbeda.

b. Kinerja merek (Brand Performance), berkenaan dengan kemampuan produk dan jasa dalam memenuhi kebutuhan fungsional konsumen.

c. Citra merek (Brand Imagery), mengacu pada sifat ekstrinsik dari produk atau jasa, yaitu kemampuan merek untuk memenuhi kebutuhan psikologis atau sosial pelanggan.

d. Penilaian merek (Brand Judgement), berfokus pada pendapat konsumen pribadi dan peringkat merek berdasarkan kinerja merek dan asosiasi citra yang dirasakan.

e. Perasaan merek (Brand Feelings), yaitu respon dan reaksi emosional konsumen terhadap merek.

f. Resonansi merek (Brand Resonance), mengacu pada karakteristik relasi yang dirasakan pelanggan terhadap merek spesifik.

\section{Kualitas Jasa}

Menurut Fandy Tjiptono (2018:268) definisi kualitas jasa berfokus pada upaya memenuhi kebutuhan dan keinginan pelanggan serta ketepatan penyampaian untuk menyeimbangkan 
harapan pelanggan. Dapat ditekankan dari teori tersebut bahwa kualitas pelayanan terhadap konsumen berupaya pemenuhan kebutuhan dan keinginan konsumen serta ketepatan penyampaian dalam mengimbangi harapan konsumen.

Manfaat Kualitas Pelayanan

Menurut Edvarsdsson dalam buku Tjiptono dan Chandra (2011:171-173), produktivitas biasanya selalu dikaitkan dengan kualitas dan profitabilitas. Meskipun demikian ketiga konsep tersebut memiliki penekanan yang berbeda-beda:

a) Produktivitas menekankan pemanfaatan (utilisasi) sumber daya, yang seringkali diikuti dengan penekanan biaya dan rasionalisasi modal. Fokus utamanya terletak pada produksi/operasi.

b) Kualitas lebih menekankan aspek kepuasan pelanggan dan pendapatan. Fokus utamanya adalah customer utility.

c) Profitabilitas merupakan hasil dari hubungan antara penghasil (uncome), biaya, dan modal yang digunakan.

Perusahaan dapat meningkatkan pangsa pasarnya melalui pemenuhan kualitas yang bersifat customer-driven yang akan memberikan keunggulan harga dan customer value. Customer value merupakan kombinasi dari manfaat dan pengorbanan yang terjadi apabila pelanggan menggunakan suatu barang atau jasa guna memenuhi kebutuhan tertentu. Jika kualitas yang dihasilkan superior dan pangsa pasar yang dimiliki besar, maka profitabilitasnya terjamin. Manfaat superior meliputi:

a) Loyalitas pelanggan yang besar

b) Pangsa pasar lebih besar

c) Harga saham yang lebih tinggi

d) Harga jual produk / jasa lebih tinggi

e) Produk vitas yang lebih besar

\section{Kerangka Pemikiran :}

Kerangka pemikiran dalam penelitian ini berdasarkan pada fenomena, kajian teori dan rumusan masalah serta hasil penelitian terdahulu yang telah diuraikan diatas sebagai berikut:

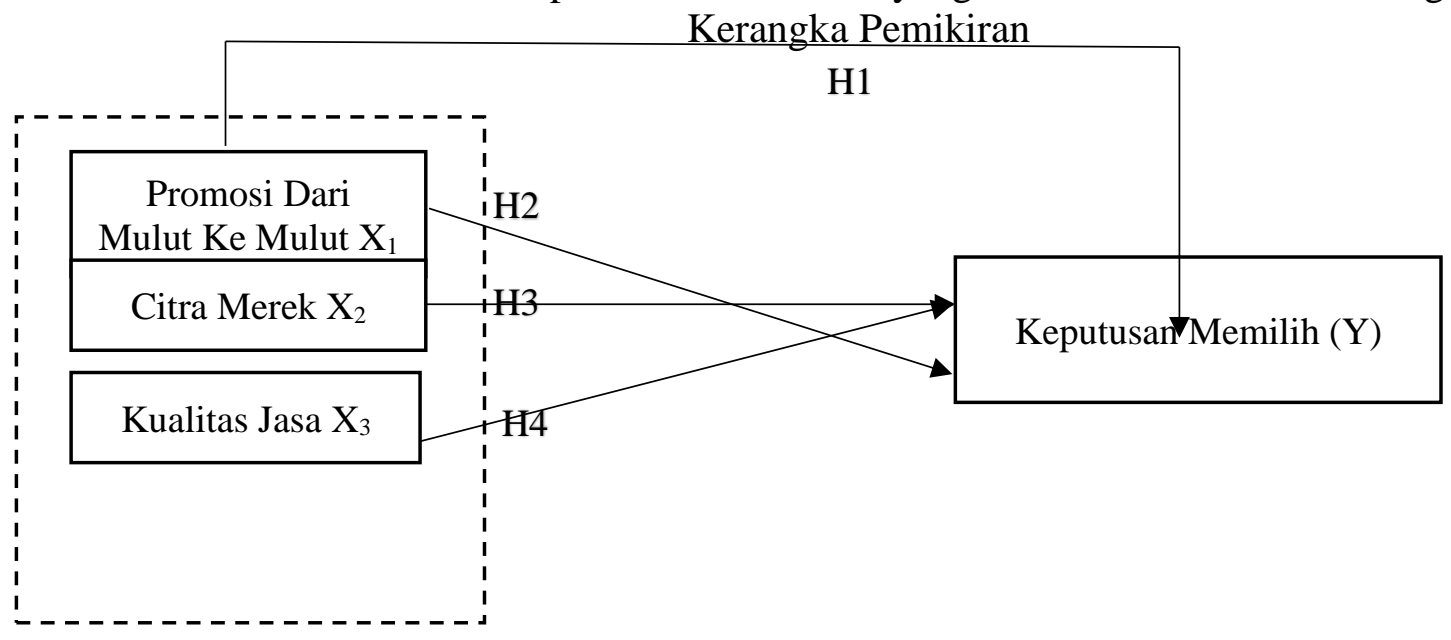

Gambar 1, Kerangka Pemikiran 


\section{Hipotesis Penelitian}

Berdasarkan landasan teori dan didukung oleh penelitian sebelumnya serta kerangka pemikiran, maka hipotesis yang dirumuskan dalam penelitian ini adalah sebagai berikut: Hipotesis yang digunakan dalam penelitian ini adalah sebagai berikut:

$\mathrm{H}_{1}$ : $\quad$ Promosi dari mulut ke mulut, Citra Merk, Kualitas Jasa berpengaruh Simultan terhadap keputusan memilih pelatihan prakerja di Pintaria

$\mathrm{H} 2$ : Promosi dari mulut ke mulut berpengaruh terhadap keputusan memilih pelatihan prakerja di Pintaria

H3 : Citra merek berpengaruh terhadap keputusan memilih pelatihan prakerja di Pintaria

H4: Kualitas Jasa berpengaruh terhadap keputusan memilih pelatihan prakerja di Pintaria

\section{METODE PENELITIAN}

\section{Hipotesis Penelitian :}

Ho1 : $\beta \leq \mathrm{O}=$ Promosi Dari Mulut Ke Mulut, Citra Merek, dan Kualitas Jasa berpengaruh terhadap Keputusan Memilih Pelatihan Prakerja di Pintaria.

Ha1 : $\beta>\mathrm{O}=$ Promosi Dari Mulut Ke Mulut, Citra Merek, dan Kualitas Jasa berpengaruh terhadap Keputusan Memilih Pelatihan Prakerja di Pintaria.

Ho2 : $\beta \leq \mathrm{O}=$ Promosi Dari Mulut Ke Mulut berpengaruh terhadap Keputusan Memilih Pelatihan Prakerja di Pintaria

Ha2 $: \beta>\mathrm{O}=$ Promosi Dari Mulut Ke Mulut tidak berpengaruh terhadap Keputusan Memilih Pelatihan Prakerja di Pintaria

Ho3 : $\beta>\mathrm{O}=$ Citra Mereka berpengaruh terhadap Keputusan Memilih Pelatihan Prakerja di Pintaria

Ha3 $: \beta>\mathrm{O}=$ Citra Merek tidak berpengaruh terhadap Keputusan Memilih Pelatihan Prakerja di Pintaria

Ho4 : $\beta>\mathrm{O}=$ Kualitas Jasa berpengaruh terhadap Keputusan Memilih Pelatihan Prakerja di Pintaria

Ha4 : $\beta>\mathrm{O}=$ Kualitas Jasa terhadap Keputusan Memilih Pelatihan Prakerja di Pintaria

\section{Variabel Penelitian dan Skala Pengukuran \\ Variabel Penelitian}

Variabel Terikat / Dependen (Y)

Variabel terikat adalah variabel yang diduga sebab akibat atau Variabel yang dipengaruhi oleh Variabel yang mendahuluinya, variabel bebas.

Keputusan Pembelian (Y)

Menurut Tjiptono dan Anastasia (2020:60), Keputusan pembelian adalah serangkaian proses yang dimulai dengan mengidentifikasi kebutuhan konsumen, mencari informasi tentang produk atau merek tertentu, dan mengevaluasi seberapa baik masing-masing alternatif tersebut mengarah pada keputusan pembelian.

Variabel Bebas / Independen (X)

Menurut Sugiono (2019:39) variabel ini sering disebut variabel stimulus, predictor, antecedent. Variabel bebas adalah merupakan variabel yang mempengaruhi atau yang menjadi sebab perubahannya atau timbulnya variabel dependen (terikat). Dalam penelitian ini variabel independen adalah sebagai berikut :

a. Promosi Dari Mulut Ke Mulut 
Menurut Kotler dan Keller (2016:652) Promosi dari mulut ke mulut adalah cara untuk membuat pelanggan berbicara positif dengan orang lain tentang produk, layanan, dan merek

b. Citra Merek

Menurut Kotler \& Keller (2018:148) mendefinisikan citra merek sebagai persepsi dan keyakinan konsumen yang tercermin dalam asosiasi yang tersimpan di benak konsumen

c. Kualitas Jasa

Menurut Fandy Tjiptono (2018:268), Definisi Kualitas Jasa berfokus pada upaya memenuhi kebutuhan dan keinginan pelanggan serta ketepatan penyampaian untuk menyeimbangkan harapan pelanggan.

\section{Skala Pengukuran}

Skala dalam penelitian ini menggunakan skala likert. Menurut Sugiyono (2019:93) skala likert digunakan untuk mengukur sikap, pendapat, dan persepsi seseorang atau sekelompok orang tentang fenomena sosial. Dalam penelitian ini skala Likert dengan angka pilihan yang diarahkan dengan nilai terendah minimal 1 dan tertinggi maksimal 5 dengan pilihan

\section{Skala Likert}

\begin{tabular}{|c|c|c|}
\hline Kode & Kriteria Jawaban & Nilai \\
\hline STS & Sangat Tidak Setuju & 1 \\
\hline TS & Tidak Setuju & 2 \\
\hline R & Ragu-ragu & 3 \\
\hline S & Setuju & 4 \\
\hline SS & Sangat Setuju & 5 \\
\hline
\end{tabular}

\section{Populasi}

Populasi dalam penelitian ini adalah peserta kartu Prakerja yang memilih pelatihan di Pintaria. Teknik pengambilan sampel pada penelitian ini adalah Nonprobability Sampling. Menurut Sugiyono (2019:84) Nonprobability Sampling adalah Teknik pengambilan sampel yang tidak memberi peluang yang sama bagi setiap unsur atau anggota populasi untuk dipilih menjadi anggota sampel.Metode pengambilan sampel pada penelitian ini adalah dengan menggunakan Accidental Sampling.

\section{PEMBAHASAN DAN HASIL PENELITIAN}

\section{Hasil Penyebaran Kuesioner}

Karakteristik Responden

\begin{tabular}{|c|c|l|c|c|}
\hline \multirow{2}{*}{1} & \multirow{3}{*}{1} & \multicolumn{1}{|c|}{$\begin{array}{c}\text { Karakteristik } \\
\text { Responden }\end{array}$} & $\begin{array}{c}\text { Frekuensi } \\
\text { (Orang) }\end{array}$ & Persentase \\
\hline \multirow{3}{*}{2} & \multirow{3}{*}{ Umur } & $<20$ tahun & 3 & $6 \%$ \\
\cline { 4 - 5 } & & $21-30$ tahun & 43 & $86 \%$ \\
\cline { 3 - 5 } & \multirow{3}{*}{ Pekerjaan } & $31-40$ tahun & 4 & $8 \%$ \\
\cline { 3 - 5 } & & Pegawai Swasta & 17 & $34 \%$ \\
\cline { 3 - 5 } & & Wiraswasta & 7 & $14 \%$ \\
\cline { 3 - 5 } & Dan Lain - Lain & 26 & $52 \%$ \\
\hline
\end{tabular}




\section{Uji Validitas Instrumen}

Hasil penyebaran kuesioner kepada 30 responden yang selanjutnya dilakukan pertabulasian data serta pengolahan data melalu software SPSS versi 24. Validitas adalah suatu ukuran yang menunjukan tingkat-tingkat kevalidan dan kesahihan suatu instrumen. Kuesioner yang disebar datanya sudah dinyatakan valid karena semua variabel memiliki nilai $r$ hitung $>0,361$ dari nilai $r$ tabel yang diolah melalui SPSS.

\section{Uji Reliabilitas}

Hasil uji reliabilitas dari masing-masing instrumen variabel menggunakan teknik Cronbach's Alpha dapat dilihat pada tabel dibawah ini:

Hasil Uji Reliabilitas

\begin{tabular}{|l|c|c|c|c|}
\hline \multicolumn{1}{|c|}{ Variabel } & $\begin{array}{c}\text { Jumlah } \\
\text { item }\end{array}$ & $\begin{array}{c}\text { Cronbach's } \\
\text { Alpha }\end{array}$ & Kriteria & Ket. \\
\hline Keputusan Memilih & 28 & 0,848 & 0,6 & Reliabel \\
\hline Promosi Dari Mulut Ke Mulut & 13 & 0,823 & 0,6 & Reliabel \\
\hline Citra Merek & 18 & 0,847 & 0,6 & Reliabel \\
\hline & & & & \\
\hline Kualitas Jasa & 24 & 0,860 & 0,6 & Reliabel \\
\hline
\end{tabular}

\section{Uji Asumsi Dasar Normalitas}

\section{One-Sample Kolmogorov-Smirnov Test}

\begin{tabular}{|c|c|c|c|c|c|}
\hline & & $\begin{array}{c}\text { Keputusan } \\
\text { Memilih }\end{array}$ & $\begin{array}{l}\text { Promosi } \\
\text { Dari Mulut } \\
\text { Ke Mulut }\end{array}$ & $\begin{array}{l}\text { Citra } \\
\text { Merek }\end{array}$ & $\begin{array}{c}\text { Kualitas } \\
\text { Jasa }\end{array}$ \\
\hline $\mathrm{N}$ & & 50 & 50 & 50 & 50 \\
\hline \multirow[t]{2}{*}{ Normal Parameters ${ }^{a, b}$} & Mean & 106.9800 & 44.8000 & 69.4000 & 91.5600 \\
\hline & Std. Deviation & 9.54579 & 6.22044 & 6.37277 & 8.22679 \\
\hline \multirow[t]{3}{*}{ Most Extreme Differences } & Absolute & .082 & .111 & .121 & .113 \\
\hline & Positive & .082 & .082 & .121 & .097 \\
\hline & Negative & -.076 & -.111 & -.074 & -.113 \\
\hline Test Statistic & & .082 & .111 & .121 & .113 \\
\hline Asymp. Sig. (2-tailed) & & $.200^{\mathrm{c}, \mathrm{d}}$ & $.174^{\mathrm{c}}$ & $.065^{c}$ & $.149^{c}$ \\
\hline
\end{tabular}

Berdasarkan tabel Uji Normalitas menggunakan uji statistic non parametik Kolmogorov Smirnov (K-S), dapat dilihat dari nilai Asymp. Sig. (2-tailed) pada Keputusan Memilih adalah 0.200, Promosi Dari Mulut Ke Mulut adalah 0.174, Citra Merek adalah 0.065, dan Kualitas Jasa adalah .0149. Sehingga dapat dilihat bahwa nilai signifikasi dari tiap tiap variabel $>0,05$ dapat dikatakan bahwa asumsi yang diisyaratkan untuk uji regresi tersebut berdistribusi normal atur dengan kata lain bahwa model regresi ini dapat dilanjutkan

\section{Uji Asumsi Klasik}

\section{Uji Normalitas Data}

a. Metode P-Plot

Metode yang lebih handal dalam uji normalitas adalah dengan melihat probability plot yang 
membandingkan distribusi kumulatif dari distribusi normal. Jika distribusi data residual normal, maka garis yang menggambarkan data sesungguhnya akan mengikuti garis diagonalnya, Ghozali (2016:54).

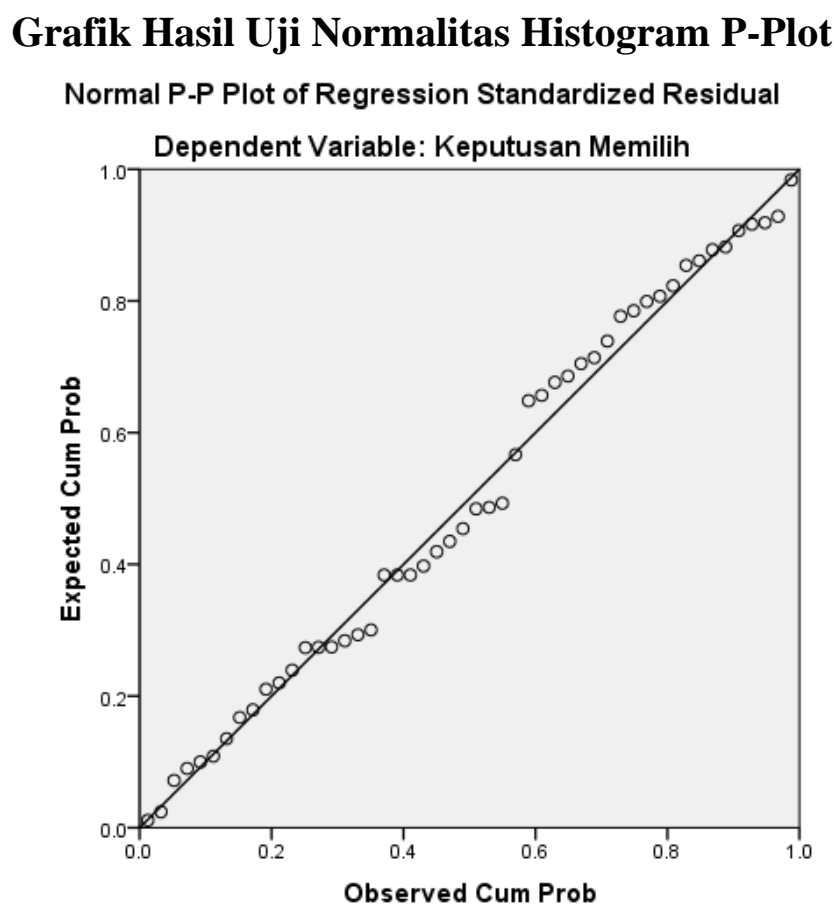

Berdasarkan pada grafik di atas, terlihat titik titik menyebar mendekati garis diagonal. Hal ini menunjukan bahwa data terdistribusi dengan normal. Selain menggunakan grafik, peneliti ini juga menggunakan uji Kolmogorov Smirnov untuk uji normalitasnya.

b. Metode Kolmogrov - Smirnov

Apabila nilai signifikasi Kolmogrov-Smirnov adalah lebih kecil dari 0.05 maka Ha diterima, sehingga data residual tidak berdistribusi normal. Sebaliknya apabila nilai signifikasi Kolmogrov-Smirnov adalah lebih besar dari 0.05 maka Ha ditolak, sehingga dari residual berdistribusi normal (Imam Ghozali 2013).

\section{Tabel 4.9}

Hasil Uji Normalitas Kolmogrov-Smirnov One-Sample Kolmogorov-Smirnov Test

\begin{tabular}{|c|c|c|}
\hline & & $\begin{array}{l}\text { Standardized } \\
\text { Residual }\end{array}$ \\
\hline \multicolumn{2}{|l|}{$\mathrm{N}$} & 50 \\
\hline \multirow[t]{2}{*}{ Normal Parameters ${ }^{a, b}$} & Mean & .0000000 \\
\hline & Std. Deviation & 5.26558643 \\
\hline \multirow[t]{3}{*}{ Most Extreme Differences } & Absolute & .077 \\
\hline & Positive & .077 \\
\hline & Negative & -.071 \\
\hline \multicolumn{2}{|l|}{ Test Statistic } & .077 \\
\hline \multicolumn{2}{|c|}{ Asymp. Sig. (2-tailed) } & $.200^{\mathrm{c}, \mathrm{d}}$ \\
\hline \multicolumn{3}{|c|}{$\begin{array}{l}\text { a. Test distribution is Normal. } \\
\text { b. Calculated from data. } \\
\text { c. Lilliefors Significance Correction. } \\
\text { d. This is a lower bound of the true significance. }\end{array}$} \\
\hline
\end{tabular}


Sumber: Hasil Pengolahan Data, 2021

Berdasarkan tabel Uji Normalitas menggunakan uji statistic non parametik Kolmogorov Smirnov (K-S) secara residual, dapat dilihat dari nilai Asymp. Sig. (2-tailed) adalah 0.200. Sehingga dapat dilihat bahwa nilai signifikasi dari tiap tiap variabel $>0,05$ dapat dikatakan bahwa asumsi yang diisyaratkan untuk uji regresi tersebut berdistribusi normal atur dengan kata lain bahwa model regresi ini dapat dilanjutkan.

\section{Uji Multikolinearitas}

Uji multikolinieritas bertujuan untuk menguji apakah dalam model regresi ditemukan adanya korelasi antara variabel independent. Jika ada korelasi yang tinggi antara variabel independent tersebut, maka hubungan antara variabel independent dengan variabel dependen akan terganggu. Model regresi yang baik seharusnya tidak terjadi multikoliniearitas. Nilai tolerance dan VIF (Variance Inflation Factor). Untuk bebas dari masalah multikolinieritas nilai tolerance harus $>0.10$ dan VIF $<10$. (Ghozali, 2013)

\section{Hasil Uji Multikoloneritas}

\begin{tabular}{|c|c|c|c|c|c|c|c|c|}
\hline \multicolumn{9}{|c|}{ Coefficients $^{a}$} \\
\hline \multirow[b]{2}{*}{ Model } & & \multicolumn{2}{|c|}{$\begin{array}{l}\text { Unstandardized } \\
\text { Coefficients }\end{array}$} & \multirow{2}{*}{$\begin{array}{c}\text { Standardized } \\
\text { Coefficients } \\
\text { Beta }\end{array}$} & \multirow{2}{*}{$\mathrm{t}$} & \multirow{2}{*}{ Sig. } & \multicolumn{2}{|c|}{ Collinearity Statistics } \\
\hline & & $\mathrm{B}$ & Std. Error & & & & Tolerance & VIF \\
\hline 1 & (Constant) & 17.918 & 9.185 & & 1.951 & .057 & & \\
\hline & $\begin{array}{l}\text { Promosi Dari } \\
\text { Mulut Ke Mulut }\end{array}$ & .416 & .189 & .273 & 2.204 & .033 & .420 & 2.383 \\
\hline & Citra Merek & 257 & .217 & .173 & 1.183 & .243 & .302 & 3.315 \\
\hline & Kualitas Jasa & .573 & .133 & .498 & 4.303 & .000 & .481 & 2.079 \\
\hline
\end{tabular}

a. Dependent Variable: Keputusan Memilih

Sumber: Hasil Pengolahan Data, 2021

Berdasarkan tabel diatas dapat diketahui bahwa nilai Tolerance untuk variabel Promosi Dari Mulut Ke Mulut (X1) adalah sebesar 0.420, Citra Merek (X2) adalah sebesar 0.302, dan Kualitas Jasa (X3) adalah sebesar 0.481. sedangkan nilai VIF (Variance Inflation Factor) untuk variabel Promosi Dari Mulut Ke Mulut (X1) adalah sebesar 2.383, Citra Merek (X2) adalah sebesar 3.315, dan Kualitas Jasa (X3) adalah sebesar 2.079.

Maka dapat disimpulkan bahwa tidak terjadi multikolinieritas antar variabel bebas, karena nilai Tolerance untuk masing-masing variabel adalah lebih besar dari 0.1 dan nilai VIF (Variance Inflation Factor) untuk masing-masing variabel lebih kecil dari 10.

\section{Uji Heteroskedasitas}

Uji Heterokedasitas bertujuan untuk menguji apakah dalam model regresi terjadi ketidaksamaan variance dari residual satu pengamatan kepengamatan yang lain. Dasar kriteria pengambilan keputusan, jika ada pola tertentu yang teratur (bergelombang, melebar, kemudian menyempit), maka terjadi heteroskedasitas jika tidak ada pola jelas, seperti titik-titik menyebar diatas dan dibawah angka 0 pada sumbu Y, maka tidak terjadi heteroskedasitas (Duwi Priyatno 2014:113). 


\section{Hasil Uji Heteroskedasitas}

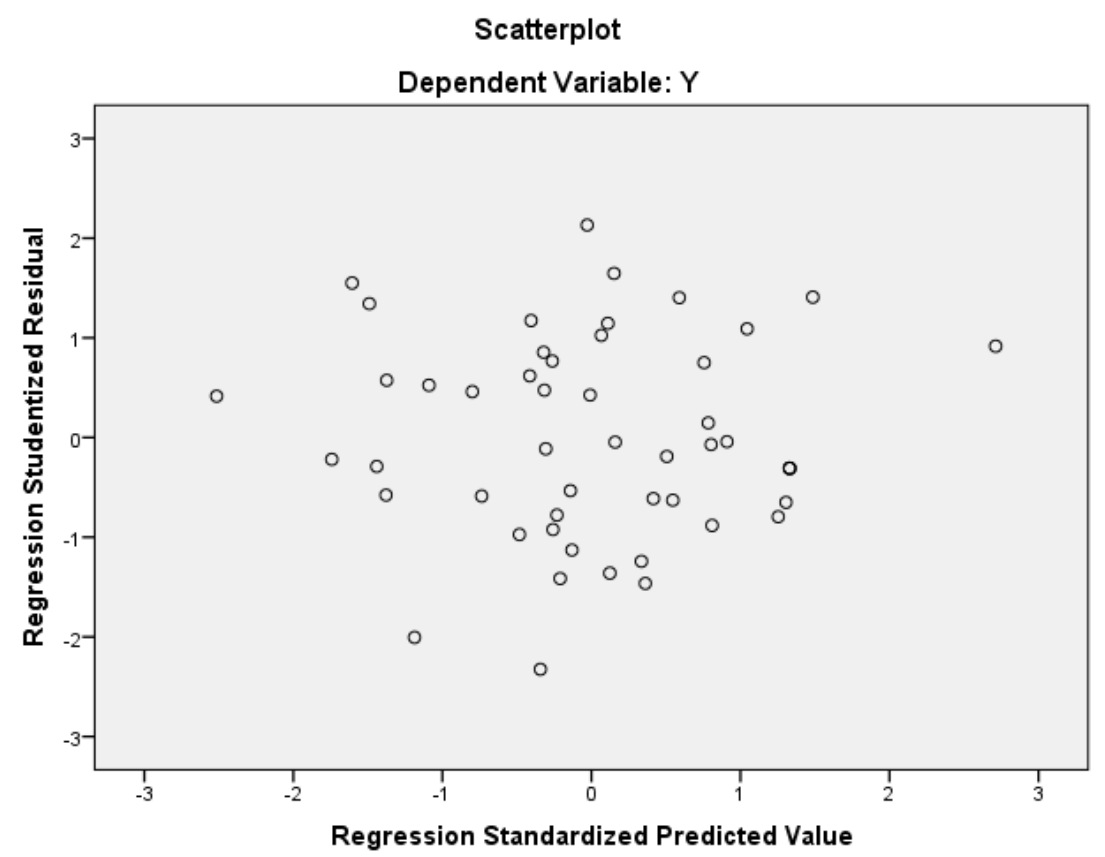

Dari output diatas dapat diketahui bahwa titik-titik membentuk pola yang jelas, dan titik-titik menyebar diatas dan dibawah angka 0 pada sumbu Y. Jadi dapat disimpulkan bahwa tidak terjadi heterokedasitas dalam model regresi.

\section{Uji Autokolerasi}

Menurut Duwi Priyatno (2014: 165), uji autokorelasi adalah korelasi antara anggota yang mengamati yang diurutkan berdasarkan waktu atau tempat. Metode pengujian menggunakan uji Durbin-Watson (DW test). Pengambilan keputusan pada uji Durbin-Watson sebagai berikut:

1. DU < DW < 4-DU maka Ho diterima, artinya tidak terjadi autokolerasi

2. DW < DL atau DW > 4-DL, maka Ho ditolak, artinya terjadi autokorelasi

3. DL $<$ DW $<$ DU atau 4 DU $<$ DW $<4$ :DL, artinya tidak ada kepastian atau kesimpulan yang pasti

\section{Hasil Autokorelasi}

\begin{tabular}{|c|c|c|c|c|c|}
\hline \multirow[b]{2}{*}{ Model } & \multicolumn{4}{|c|}{ Model Summary ${ }^{b}$} & \multirow[b]{2}{*}{ Durbin-Watson } \\
\hline & $\mathrm{R}$ & R Square & $\begin{array}{l}\text { Adjusted R } \\
\text { Square }\end{array}$ & $\begin{array}{l}\text { Std. Error of the } \\
\text { Estimate }\end{array}$ & \\
\hline 1 & $.839^{a}$ & .704 & .684 & 5.32345 & 2.023 \\
\hline
\end{tabular}

Sumber: Hasil Pengolahan Data, 2021

Penelitian ini menggunakan Uji Durbin Watson (DW test) sebagai analisis data. Dimana nilai DL dan DU diperoleh dengan melihat tabel statistic Durbin Watson pada tingkat signifikansi a $=5 \%, \mathrm{k}=3$ (jumlah variabel bebas yaitu X1,X2,X3), kemudian diperoleh nilai $\mathrm{DL}=1.420$ dan nilai $\mathrm{DU}=1.673$ dengan $\mathrm{n} 50$ (jumlah responden), nilai $\mathrm{DW}=2.023$ yang diperoleh dari hasil pengolahan data dan 4-DU $=2.327$ dengan SPSS versi 24. Karena nilai Durbin Watson terletak antara DU $\leq \mathrm{DW} \leq 4$-DU adalah $(1.673<2.023<2.327)$ artinya tidak terjadi autokorelasi. 


\section{Uji Hipotesis}

1. Uji Regresi Linear Berganda

Hasil Analisis Regresi Linear Berganda

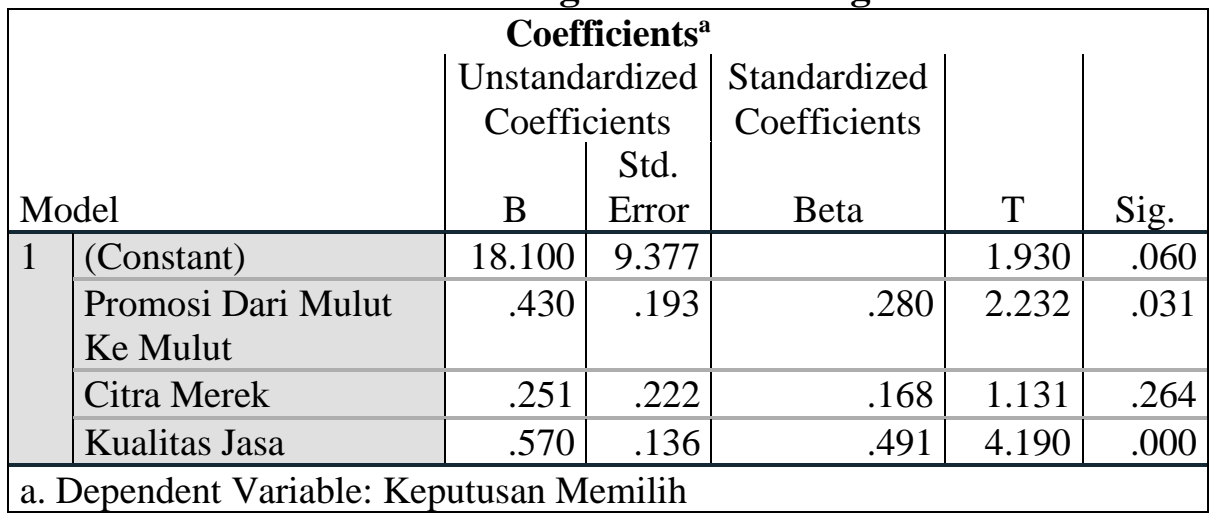

Sumber : Hasil Pengolahan Data, 2021

Persamaan regresi berganda berdasarkan hasil analisis regresi dapat diketahui sebagai berikut:

$$
\mathrm{Y}=18,100+0,430+0,251+0,570
$$

Adapun penjelasan dari persamaan regresi linear berganda diatas adalah sebagai berikut:

a) Nilai konstanta sebesar 18,100 artinya apabila Promosi Dari Mulut Ke Mulut, Citra Merek dan Kualitas Jasa sama dengan 0 (tidak melakukan kegiatan), maka keputusan memilih tetap memiliki nilai konstanta 18,100.

b) Nilai koefisien Promosi Dari Mulut Ke Mulut sebesar 0,430, artinya apabila Promosi Dari Mulut Ke Mulut mengalami kenaikan 1, maka Keputusan Memilih pelatihan prakerja di Pintaria akan mengalami peningkatan sebesar 0,430 .

c) Nilai koefisien Citra Merek sebesar 0,251, artinya apabila Citra Merek mengalami kenaikan 1, maka Keputusan Memilih pelatihan prakerja di Pintaria akan mengalami peningkatan sebesar 0,251 .

d) Nilai koefisien Kualitas Jasa sebesar 0,570, artinya apabila Kualitas Jasa mengalami kenaikan 1, maka Keputusan Memilih pelatihan prakerja di Pintaria akan mengalami peningkatan sebesar 0,570 .

\section{Uji Simultan (uji F)}

Uji F menunjukan apakah semua variabel independen memiliki pengaruh secara bersamasama terhadap variabel dependen. Kriteria pengambilan keputusannya dengan tingkat signifikansi $(0,05)$ adalah dengan membandingkan nilai $F_{\text {hitung }}$ dengan $F_{\text {tabel. }}$.

- Jika $F_{\text {hitung }}>F_{\text {tabel }}$ maka, Ho ditolak

- Jika $F_{\text {hitung }}<F_{\text {tabel }}$ maka, Ho diterima

Berdasarkan signifikansi

- Jika signifikansi > 0,05 maka Ho diterima

- Jika signifikansi < 0,05 maka Ho ditolak 


\section{Hasil Uji Signifikansi F}

\begin{tabular}{|c|c|c|c|c|c|c|}
\hline \multicolumn{7}{|c|}{ ANOVA $^{\mathrm{a}}$} \\
\hline \multicolumn{2}{|c|}{ Model } & $\begin{array}{l}\text { Sum of } \\
\text { Squares }\end{array}$ & Df & $\begin{array}{l}\text { Mean } \\
\text { Square }\end{array}$ & $\mathrm{F}$ & Sig. \\
\hline \multirow[t]{3}{*}{1} & Regression & 3106.386 & 3 & 1035.462 & 35.059 & $.000^{\mathrm{b}}$ \\
\hline & Residual & 1358.594 & 46 & 29.535 & & \\
\hline & Total & 4464.980 & 49 & & & \\
\hline & $\begin{array}{l}\text { endent Vari } \\
\text { ictors: (Cor } \\
\text { lerek }\end{array}$ & $\begin{array}{l}\text { Keputusan } \\
\text { Kualitas }\end{array}$ & $\begin{array}{l}\text { emil } \\
\text { sa, } \mathrm{Pr}\end{array}$ & osi $\mathrm{D}$ & 1. & lut, \\
\hline
\end{tabular}

Sumber: Hasil Pengolahan Data, 2021

Dari hasil uji F / ANOVA diperoleh $\mathrm{F}_{\text {hitung }}$ sebesar 35,059 df $=(\mathrm{n}-4)=50-4=46$. Hasil diperoleh $F_{\text {tabel }}$ sebesar 2,807. Nilai $F_{\text {hitung }}>F_{\text {tabel }}(35,059>2,807)$ dan nilai probabilitas (signifikan) adalah sebesar 0,000, karena nilai signifikansi $0,000<0,5$. Maka dapat disimpulkan bahwa variabel Promosi Dari Mulut Ke Mulut (X1), Citra Merek (X2), dan Kualitas Jasa (X3) secara bersamaan atau simultan berpengaruh positif terhadap Keputusan Memilih (Y) di Pintaria. Dengan demikian $\mathrm{H}_{0}$ ditolak dan $\mathrm{H}_{\mathrm{a}}$ diterima.

\section{Uji Parsial (uji t)}

Uji t dipakai untuk mengetahui kebenaran pernyataan atau dugaan yang dihipotesiskan oleh. Untuk mengetahui pengaruh - pengaruh dari variabel bebas terhadap dependen. Kriteria pengujian pada Uji t menurut Duwi Priyatno (2017:175) adalah sebagai berikut:

- $\quad$ Jika $t_{\text {hitung }}>\mathrm{t}_{\text {tabel }}$ maka, $\mathrm{H}_{0}$ ditolak

- $\quad$ Jika $t_{\text {hitung }}<\mathrm{t}_{\text {tabel }}$ maka, $\mathrm{H}_{0}$ diterima

Berdasarkan signifikansi

- Jika signifikansi > 0,05 maka, $\mathrm{H}_{0}$ diterima

- Jika signifikansi $<0,05$ maka, $\mathrm{H}_{0}$ ditolak

Menentukan $t_{\text {tabel }}$ dapat dilihat pada tabel signifikansi $0,05 / 2=0,025$ dengan derajat kebebasan $\mathrm{df}=\mathrm{n}-\mathrm{k}-1$ atau $50-3-1=46$ adalah jumlah responden, maka didapat nilai $\mathrm{t}_{\text {tabel }}$ $=2.013$

\section{Hasil Uji Signifikansi t}

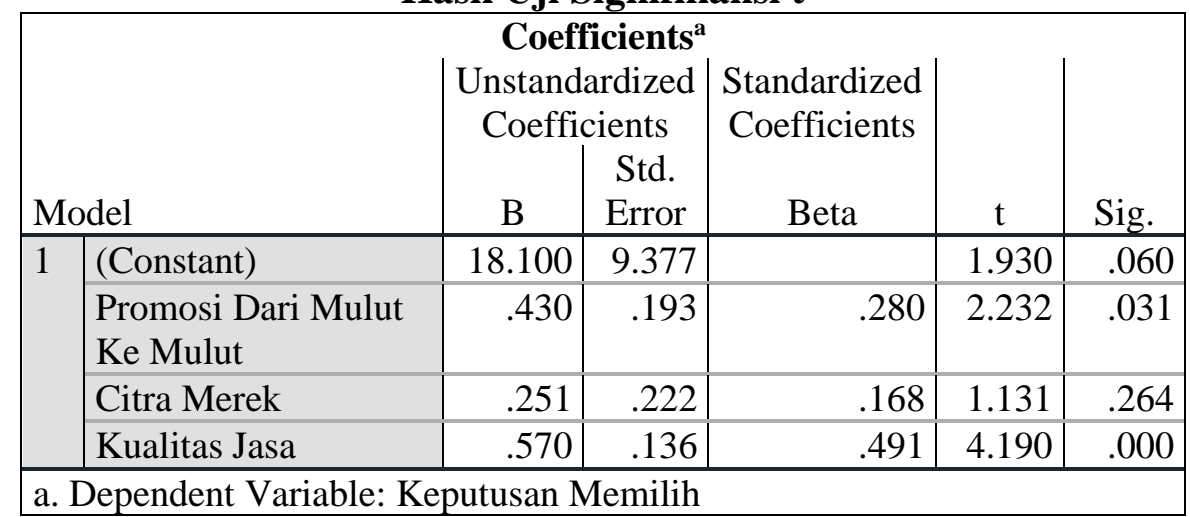

Sumber: Hasil Pengolahan Data, 2021

Berdasarkan tabel Hasil uji t menunjukan hasil sebagai berikut

a) Variabel Promosi Dari Mulut Ke Mulut (X1) nilai $t_{\text {hitung }}>t_{\text {tabel }}(2,232>2,013)$ dan nilai signifikansi $(0,031<0,05)$ dengan demikian $\mathrm{H}_{0}$ ditolak dan $\mathrm{H}_{\mathrm{a}}$ diterima, yang artinya secara parsial Promosi Dari Mulut Ke Mulut berpengaruh signifikan terhadap Keputusan Memilih 
b) Variabel Citra Merek (X2) nilai thitung $>$ tabel $(1,131<2,013)$ dan nilai signifikansi $(0,264>$ $0,05)$ dengan demikian $\mathrm{H}_{0}$ diterima dan $\mathrm{H}_{\mathrm{a}}$ ditolak, yang artinya secara parsial Citra Merek tidak berpengaruh terhadap Keputusan Memilih

c) Variabel Kualitas Jasa (X3) nilai thitung $>t_{\text {tabel }}(4,190>2,013)$ dan nilai signifikansi $(0,000$ $<0,05)$ maka $\mathrm{H}_{04}$ ditolak dan $\mathrm{H}_{\mathrm{a}}$ diterima, yang artinya secara parsial Kualitas Jasa berpengaruh signifikan terhadap Keputusan Memilih.

4. Uji Koefisien Determinasi

Koefisien determinasi bertujuan untuk mengetahui seberapa besar kemampuan variabel independen menjelaskan variabel dependen. Menurut Duwi Priyatno (2017:156) Koefisien determinasi Adjusted R Square adalah R Square yang telah disesuaikan, nilai sebesaran Adjusted R Square ini juga menunjukan sumbangan pengaruh variabel independen terhadap variabel dependen. Adjusted R Square biasanya untuk mengukur sumbangan pengaruh jika dalam regresi menggunakan lebih dari dua variabel independen.

\section{Hasil Koefisien Determinasi (R2)}

\begin{tabular}{|c|c|c|c|c|c|}
\hline \multicolumn{6}{|c|}{ Model Summary $^{\mathbf{b}}$} \\
\hline $\begin{array}{l}\text { Mod } \\
\text { el }\end{array}$ & $\mathrm{R}$ & R Square & $\begin{array}{l}\text { Adjusted } \\
\text { R Square }\end{array}$ & $\begin{array}{l}\text { Std. Error of the } \\
\text { Estimate }\end{array}$ & $\begin{array}{l}\text { Durbin- } \\
\text { Watson }\end{array}$ \\
\hline 1 & $.834^{\mathrm{a}}$ & .696 & .676 & 5.43458 & 2.035 \\
\hline
\end{tabular}

Sumber: Hasil Pengolahan Data, 2021

Berdasarkan tabel dapat dilihat bahwa nilai $\mathrm{R}$ menunjukan korelasi sederhana antara variabel $\mathrm{X}$ terhadap variabel Y diperoleh nilai 0,834 artinya korelasi antara variabel X (Promosi Dari Mulut Ke Mulut, Citra Merek, dan Kualitas Jasa) terhadap Keputusan Memilih sebesar 0,834. Hal ini berarti hubungan yang kuat karena nilai diatas $>0,50$ dan mendekati 1 .

Nilai R2 adalah 0,696 dan nilai Adjusted R2 sebesar 0,676. Dalam hal ini berarti 67,6\% menunjukan bahwa persentase sumbangan pengaruh variabel independen (Promosi Dari Mulut Ke Mulut, Citra Merek, dan Kualitas Jasa) terhadap variabel dependen. Sedangkan sisanya $32,4 \%(100 \%$ - 67,6\%) dipengaruhi atau dijelaskan oleh variabel lain yang tidak diketahui dan tidak termasuk dalam penelitian ini.

\section{Pembahasan dan Interpretasi Hasil Penelitian}

Penelitian ini dilakukan untuk membahas faktor-faktor yang mempengaruhi keputusan memilih pelatihan prakerja di Pintaria. Faktor-faktor tersebut terbatas pada faktor Promosi Dari Mulut Ke Mulut (X1), Citra Merek (X2), dan Kualitas Jasa (X3) terhadap Keputusan Memilih Pelatihan Kerja di Pintar

1. Pengaruh Promosi Dari Mulut Ke Mulut (X1), Citra Merek (X2), dan Kualitas Jasa (X3) Terhadap Keputusan Memilih (Y)

Berdasarkan hasil perhitungan dapat disimpulkan bahwa Promosi Dari Mulut Ke Mulut (X1), Citra Merek (X2), dan Kualitas Jasa (X3) dalam penelitian ini berpengaruh secara positif, sehingga memiliki pengaruh sebesar $67,6 \%$ dan sisanya $32,4 \%$ dipengaruhi oleh variabel lain yang tidak dijelaskan dalam penelitian ini. 
Volume 6 No 2 Februari 2022

P-ISSN : 2528-7044

E-ISSN : 2809-5103

DOI: https://doi.org/10.54964/manajemen/

\section{Pengaruh Promosi Dari Mulut Ke Mulut (X1) Terhadap Keputusan Memilih (Y)}

Berdasarkan hasil dari penelitian ini diketahui bahwa Promosi Dari Mulut Ke Mulut (X1) yang ada pada Pintaria berpengaruh signifikan terhadap Keputusan Memilih. Hal ini dibuktikan dengan nilai $t_{\text {hitung }}>t_{\text {tabel }}(2,232>2,013)$ dan nilai signifikansi $(0,31<0,05)$.

Dari dimensi yang dimiliki Promosi Dari Mulut Ke Mulut yaitu: Buzz dan Viral dari kedua dimensi tersebut berdasarkan penilaian responden, dimensi yang memiliki skor paling tertinggi ialah dimensi Viral dengan nilai 3,53. Hal ini berarti terkait dengan Promosi Dari Mulut Ke Mulut tentang pendapat positif yang beredar di media sosial telah berhasil menciptakan keputusan memilih, hal ini patut dipertahankan. Dan dimensi dengan nilai terendah adalah dimensi Buzz dengan nilai 3,35. Hal ini berarti terkait Promosi Dari Mulut Ke Mulut tentang rekomendasi dari selebgram belum sepenuhnya menciptakan keputusan memilih, hal ini perlu diperbaiki dan diperhatikan kembali, karena memiliki nilai terendah. Berdasarkan hal tersebut sebaiknya Pintaria mengevaluasi kembali influencer (tokoh) agar dapat tepat sasaran pasar dan menciptakan keputusan memilih.

\section{Pengaruh Citra Merek (X2) Terhadap Keputusan Memilih (Y)}

Berdasarkan hasil dari penelitian ini diketahui bahwa Citra Merek (X2) yang ada pada Pintaria tidak berpengaruh terhadap Keputusan Memilih. Hal ini dibuktikan dengan nilai $t_{\text {hitung }}$ $>\mathrm{t}_{\text {tabel }}(1,131<2,013)$ dan nilai signifikansi $(0,264>0,05)$.

Dari dimensi yang dimiliki Citra Merek yaitu: Citra Perusahaan dan Citra Produk dari kedua dimensi tersebut berdasarkan penilaian responden, dimensi yang memiliki skor paling tertinggi ialah dimensi Citra Produk dengan nilai 3,96. Hal ini berarti terkait dengan Citra Merek tentang aplikasi yang disediakan oleh Pintaria memberikan kemudahan bagi peserta dapat mengakses pelatihan baik di hp maupun di desktop yang artinya bahwa telah berhasil menciptakan keputusan memilih, hal ini patut dipertahankan. Dan dimensi dengan nilai terendah adalah dimensi Citra Perusahaan dengan nilai 3,75. Hal ini berarti terkait Citra Merek tentang slogan yang dibuat perusahaan \#MendadakHitz belum sepenuhnya menciptakan keputusan memilih, hal ini perlu diperbaiki dan diperhatikan kembali, karena memiliki nilai terendah. Berdasarkan hal tersebut sebaiknya Pintaria bisa mengembangkan lagi citra produknya dan mengevaluasi kembali citra perusahaan mengenai slogan yang dibuat agar menciptakan keputusan memilih.

\section{Pengaruh Kualitas Jasa (X3) Terhadap Keputusan Memilih (Y)}

Berdasarkan hasil dari penelitian ini diketahui bahwa Kualitas Jasa (X3) yang ada pada Pintaria berpengaruh signifikan terhadap Keputusan Memilih. Hal ini dibuktikan dengan nilai $t_{\text {hitung }}>$ $\mathrm{t}_{\text {tabel }}(4,190>2,013)$ dan nilai signifikansi $(0,000<0,05)$.

Dari dimensi yang dimiliki Kualitas Jasa yaitu: Bukti Fisik, Kehandalan, Jaminan dan Daya Tanggap dari keempat dimensi tersebut berdasarkan penilaian responden, dimensi yang memiliki skor paling tertinggi ialah dimensi Keamanan (Jaminan) dengan nilai 3,92. Hal ini berarti terkait dengan Kualitas Jasa tentang jaminan setelah menyelesaikan pelatihan peserta mendapatkan sertifikat yang artinya bahwa telah berhasil menciptakan keputusan memilih, hal ini patut dipertahankan. Dan dimensi dengan nilai terendah adalah dimensi Citra Perusahaan dengan nilai 3,68. Hal ini berarti terkait Kualitas Jasa tentang daya tanggap fitur pada menu di website helpdesk (layanan peserta) merasa belum membantu penyelesaian masalah pada saat pelatihan berlangsung yang artinya belum sepenuhnya menciptakan keputusan memilih, hal ini perlu diperbaiki dan diperhatikan kembali, karena memiliki nilai terendah. Berdasarkan hal tersebut sebaiknya Pintaria bisa mengembangkan lagi Kualitas Jasa pada jaminannya dan mengevaluasi kembali daya tanggap helpdesk menyelesaikan permasalahan pelatihan yang 
dialami oleh peserta agar menciptakan keputusan memilih.

\section{KESIMPULAN DAN SARAN}

\section{Kesimpulan}

Dari hasil analisis penelitian yang telah dilakukan mengenai Pengaruh Promosi Dari Mulut Ke Mulut, Citra Merek, dan Kualitas Jasa terhadap Keputusan Memilih Pelatihan Prakerja di Pintaria. Terdapat kesimpulan yang dapat ditarik dari penelitian ini adalah sebagai berikut:

1. Promosi Dari Mulut Ke Mulut (X1, Citra Merek (X2), dan Kualitas Jasa (X3) secara bersamaan atau simultan berpengaruh terhadap Keputusan Memilih (Y) Pelatihan Prakerja di Pintaria

2. Promosi Dari Mulut Ke Mulut (X1) secara parsial berpengaruh terhadap Keputusan Memilih (Y).

3. Citra Merek (X2) secara parsial tidak berpengaruh terhadap Keputusan Memilih (Y).

2. Kualitas Jasa (X3) secara parsial berpengaruh terhadap Keputusan Memilih (Y).

\section{Saran}

Berdasarkan hasil penelitian di atas mengenai pengaruh Promosi Dari Mulut Ke Mulut, Citra Merek, dan Kualitas Jasa Terhadap Keputusan Memilih Pelatihan Prakerja di Pintaria, peneliti memberikan saran sebagai bahan masukan dan pertimbangan:

\section{Bagi Perusahaan}

a. Promosi Dari Mulut Ke Mulut

Menciptakan Promosi Dari Mulut Ke Mulut yang lebih baik, dengan memperhatikan dan mengevaluasi indikator terendah yaitu Informasi Tokoh dengan nilai 3.04 dengan pernyataan nomor 4 "Review atau rekomendasi dari Selebgram mempengaruhi saya memilih" berdasarkan hal ini responden menilai bahwa masih perlu diperhatikan kembali dan patut dievaluasi untuk influencer (selebgram) yang bekerjasama dengan Pintaria lebih tepat sasaran supaya melalui Informasi Tokoh lebih bisa meyakinkan peserta tertarik dan dapat menciptakan keputusan memilih.

b. Citra Merek

Membangun citra merek yang lebih baik, dengan mengevaluasi dan memperhatikan indikator yang terendah yaitu Pengaruh Merek dengan nilai 3.28 dengan pernyataan kuesioner nomor 3 "Slogan \#MendadakHits mempengaruhi saya memilih Pintaria". Berdasarkan hal tersebut Pintaria sebaiknya mengkaji ulang slogan (tagline) agar lebih dapat mempengaruhi peserta kartu Prakerja untuk memilih Pintaria.

c. Kualitas Jasa

Meningkatkan Kualitas Jasa dan memperbaiki segala kekurangan Kualitas Jasa dengan memperhatikan indikator "Mengerti" dan "Kecepatan" dengan nilai 3,58 dengan pernyataan nomor 20 "Saya merasa helpdesk (layanan peserta) dapat membantu penyelesaian masalah pelatihan" dan nomor 23 "Helpdesk (layanan peserta) cepat menyelesaikan masalah pelatihan" dalam hal ini responden menilai bahwa kemampuan helpdesk (layanan peserta) belum mampu mengerti permasalahan peserta dan belum mampu membantu menyelesaikan kendala peserta dengan cepat, maka sebaiknya diperbaiki dengan memberikan pelatihan kepada helpdesk (layanan peserta) untuk menciptakan keputusan memilih.

Bagi Peneliti Selanjutnya

Pada penelitian selanjutnya, diharapkan penelitian ini dapat menjadi bahan acuan ataupun 
pertimbangan bagi pembaca karya ilmiah lainnya, dan agar peneliti selanjutnya dapat menambahkan jumlah variabel bebas dengan variabel yang baru, dengan menggunakan data yang lebih akurat, jumlah data yang banyak, serta rentang waktu yang lebih panjang, sehingga memungkinkan hasil penelitian terhadap variabel terikat kepuasan mahasiswa dapat dijelaskan dengan lebih baik.

\section{DAFTAR PUSTAKA}

\section{Sumber Buku:}

Buchari Alma. 2018. Manajemen Pemasaran dan Pemasaran Jasa, Alfabeta. Bandung.

Duwi Priyatno. 2017. Panduan Praktis Olah Data Menggunakan SPSS, Andi Offset, Yogyakarta.

Fandy Tjiptono, Ph. D dan Anastasia Diasa. 2020, Pemasaran Esensi dan Aplikasi, Andi Offset, Yogyakarta.

Fandy Tjiptono, Ph.D. 2018. Kualitas Jasa, Andi Offset, Yogyakarta.

M. Anang Firmansyah. 2019. Pemasaran Produk dan Merek, Qiara Media, Indonesia.

M. Anang Firmansyah. 2019. Perilaku Konsumen (Sikap dan Pemasaran), Qiara Media, Indonesia.

Philip Kotler dan Kevin Lane Keller. 2016. Marketing Management 15e, Pearson Education Limited, England.

Philip Kotler dan Gary Armstrong. 2019. Prinsip-Prinsip Pemasaran, Erlangga, Jakarta.

Ratih Hurriyati. 2018. Bauran Pemasaran dan Loyalitas Konsumen, Alfabeta, Bandung.

Sugiyono. 2019. Metode Penelitian Kuantitatif, Kualitatif, dan R\&D, Alfabet, Bandung.

\section{Sumber Jurnal:}

Amalia Ghani Rizki, Kadarisman Hidayat, Lusy Deasyana Rahma Devita. 2019. "Pengaruh Citra Merek dan Harga Terhadap Keputusan Memilih Pada E-Commerce Shopee Indonesia", Jurnal Administrasi Bisnis, Vol. 72, No. 2.

Desy Irana Dewi Lubis, Rahmat Hidayat. 2017. "Pengaruh Citra Merek dan Harga terhadap Keputusan Memilih pada Sekolah Tinggi Ilmu Manajemen Sukma Medan”, Jurnal Iman, Vol. 5, No. 1.

Edi Sucipto Tanady, Muhammad Fuad. 2020, “Analisis Pengaruh Citra Merek Dan Kualitas Layanan Terhadap Keputusan Memilih Tokopedia Di Jakarta", Institut Bisnis dan Informatika Kwik Kian Gie, Vol. 9, No. 2.

Gede Wisnu Saputra, I Gusti Agung Ketut Sri Ardani. 2020, "Pengaruh Digital Marketing, Word of Mouth, Dan Kualitas Jasa Terhadap Keputusan Memilih", E-Jurnal Manajemen, Vol. 9, No. 7.

Goldianus Solangius Mbete, Rinabi Tanamal. 2020, "Effect of Easiness, Service Quality, Price, Trust of Quality of Information, and Brand Image of Consumer Purchase Decision on Shopee Online Purchase", Jurnal Informatika Universitas Pamulang, Vol. 5, No. 2.

Iskan Aryo Nugroho, I Made Bayu Dirgantara. 2021. "Pengaruh Kualitas Jasa, Citra Merek Dan Pemasaran Online Terhadap Keputusan Memilih", Dipo negoro Journal of Management, Vol.10, No. 1.

Kiki Joesyiana. 2018. "Pengaruh Word of Mouth Terhadap Keputusan Memilih Konsumen Pada Media Online Shop Shopee Di Pekanbaru", Jurnal Valuta. Vol. 4, No. 1.

Muhammad Aries Firnanda, Asnawati. 2017. "Pengaruh Electronic Word of Mouth, Brand Image, Brand Trust terhadap Keputusan Penggunaan Jasa Ojek Online Gojek di Samarinda", Prosiding Seminar Nasional Manajemen dan Ekonomi Bisnis, Vol. 1. 


\section{Jurnal Manajemen USNI}

Volume 6 No 2 Februari 2022

P-ISSN : 2528-7044

E-ISSN : 2809-5103

DOI: https://doi.org/10.54964/manajemen/

Novita Sari, Muhammad Saputra, Jamaluddin Husein. 2017. "Pengaruh Electronic Word of Mouth Terhadap Keputusan Memilih Pada Toko Online Bukalapak.com", Informatics and Business Institute Darmajaya, Vol. 3, No. 1.

\section{Sumber Lainnya:}

Halaman Facebook Pintaria X PraKerja https://bit.ly/319Expq

Instagram Prakerja https://www.instagram.com/prakerja.go.id/

Instagram Pintaria https://www.instagram.com/pintaria id/

Laporan Manajemen Pelaksana Kartu Prakerja Tahun 2020 https://bit.ly/3iaYf2f

Media Konsumen di https://mediakonsumen.com/tag/pintaria

Twitter \#Pintaria https://bit.ly/3zPO090

Ulasan Pintaria www.pintaria.com 